\title{
SIMPLIFIKASI REGULASI DENGAN MENGGUNAKAN METODE PENDEKATAN OMNIBUS LAW
}

\author{
(Simplification of Regulation Using the Omnibus Law Approach Method)
}

\author{
Wicipto Setiadi \\ Fakultas Hukum Universitas Pembangunan Nasional Veteran Jakarta \\ Jl. Fatmawati No. 1 Pondok Labu, Jakarta Sekatan 12450 \\ e-mail: wiciptosetiadi@upnvj.ac.id
}

Naskah diterima: 18 Februari 2020; revisi: 6 April 2020; disetujui: 6 April 2020

\begin{abstract}
Abstrak
Jumlah regulasi saat ini sudah terlalu banyak dan saling tidak harmonis, saling konflik, serta saling tumpang tindih antara regulasi yang satu dengan yang lain. Banyaknya regulasi sering juga disebut over regulated, banjir regulasi, atau obesitas regulasi. Artikel ini mencoba mencari langkah-langkah apa yang perlu dilakukan dalam rangka melakukan perbaikan kondisi regulasi tersebut. Penelitian diarahkan pada penelusuran kepustakaan (library research), pendekatan peraturan perundang-undangan (statute approach) dan dokumen-dokumen lain yang berkaitan dengan pokok bahasan. Dari penelusuran tersebut dihasilkan karya tulis yang sistematis dengan menggunakan pendekatan yuridis-analitis dan akan diperoleh hasil yang kualitatif. Dari hasil penelitian cara yang ditempuh untuk mengatasi kondisi regulasi yang sudah terlalu banyak dan cenderung tidak harmonis tersebut perlu dilakukan simplifikasi regulasi dengan menggunakan pendekatan omnibus law. Omnibus law adalah model penyusunan regulasi yang lazim digunakan di negara-negara dengan tradisi sistem common law.

Kata kunci: obesitas regulasi, simplifikasi regulasi, omnibus law
\end{abstract}

\begin{abstract}
The current number of regulations is too much and is not harmonious, conflicting, and overlapping with one another. The abundance of regulation is often also called over regulated, flood regulation, or obesity regulation. This article tries to find what steps need to be taken in order to improve the conditions of the regulation. The research was directed at library research, the statutory approach and other documents relating to the subject matter. From these searches a systematic writing will be produced using a juridical-analytical approach and qualitative results will be obtained. From the results of research into the ways taken to overcome the regulatory conditions that are too many and tend to be harmonious, it is necessary to simplify the regulation using the omnibus law approach. The omnibus law is a model for formulating regulations that is commonly used in countries with a common law system tradition.
\end{abstract}

Keywords: regulatory obesity, simplification of regulation, omnibus law 


\section{A. Pendahuluan}

Presiden Jokowi pada acara Rapat Koordinasi Nasional Kepala Daerah dan Forum Pimpinan Daerah yang diselenggarakan oleh Kementerian Dalam Negeri pada tanggal 13 November 2019 di Sentul menyatakan bahwa Negara kita sudah kebanyakan peraturan dan negara ini bukan "negara peraturan". Pernyataan Presiden tersebut ada benarnya karena kenyataan yang terjadi pada saat ini jumlah regulasi di negara kita memang sudah terlalu banyak. ${ }^{1}$ Berdasarkan pangkalan data (database) yang diambil dari situs peraturan. go.id per 16 Januari 2020 dari Direktorat Jenderal Peraturan Perundang-undangan Kementerian Hukum dan HAM jumlah regulasi kita dapat dilihat dalam tabel berikut ini.

Tabel 1. Jumlah Regulasi

\begin{tabular}{ll}
\hline Jenis PUU & Jumlah \\
\hline UU & 1687 \\
\hline Perppu & 180 \\
\hline PP & 4559 \\
\hline Perpres & 2016 \\
\hline Peraturan BPK & 26 \\
\hline Peraturan BI & 148 \\
\hline Peraturan OJK & $336^{2}$ \\
\hline Peraturan Menteri & $14734^{3}$ \\
\hline Peraturan LPNK & $4282^{4}$ \\
\hline Peraturan Daerah & $15965^{5}$ \\
\hline \multicolumn{1}{c}{ Total } & $\mathbf{4 3 9 3 3}$ \\
\hline
\end{tabular}

Sumber: www.peraturan.go.id per tanggal 16 Januari 2020
Selain pangkalan data peraturan.go.id, ada pangkalan data lain yang menyediakan data peraturan perundang-undangan, yaitu jdihn. go.id yang disediakan oleh Badan Pembinaan Hukum Nasional (BPHN), Kementerian Hukum dan HAM. Berdasarkan pangkalan data jdihn. go.id per tgl. 21 Januari $2020^{6}$ dapat dilihat dalam tabel-tabel berikut ini.

Tabel 2. Produk Hukum Tingkat Pusat dan Daerah

\begin{tabular}{ll}
\hline Produk Hukum & Jumlah \\
\hline Produk Hukum Tingkat Pusat & 39.990 \\
\hline Produk Hukum Tingkat Daerah & 152.617 \\
\hline Total & $\mathbf{1 9 1 . 6 0 7}$ \\
\hline
\end{tabular}

Sumber: www.jdihn.go.id pertanggal 21 Januari 2020

Tabel 3. Jenis Produk Hukum Tingkat Pusat

\begin{tabular}{ll}
\hline Produk Hukum & Jumlah \\
\hline Undang-Undang Dasar & 1 \\
\hline Ketetapan MPR & 4 \\
\hline Undang-Undang & 1670 \\
\hline Perppu & 182 \\
\hline Peraturan Pemerintah & 4542 \\
\hline Peraturan Presiden & 1831 \\
\hline Keputusan Presiden & 4852 \\
\hline Instruksi Presiden & 669 \\
\hline Undang-Undang Darurat & 178 \\
\hline Peraturan Penguasa Perang Tertinggi & 48 \\
\hline Peraturan Kementerian & 19820 \\
\hline Peraturan Lembaga Negara & 228 \\
\hline
\end{tabular}

Wicipto Setiadi, Indonesia Negara Peraturan?, Koran Sindo, Kamis, 21 November 2019.

Untuk nomor 1-7 http://peraturan.go.id/peraturan/pusat.html (diakses 16 Januari 2020).

http://peraturan.go.id/peraturan/list.html?id=11e449f371bb47e09607313231373436 (diakses16 Januari 2020).

4 http://peraturan.go.id/peraturan/list.html?id=11e45da5a04bb002ae96303235313036 (diakses16 Januari 2020).

5 http://peraturan.go.id/peraturan/list.html?id=11e449f37c133b90991d313231383033 (diakses16 Januari 2020).

6 http://www.jdihn.go.id (diakses 21 Januari 2020). 
RUECHTSVINDING

Media Pembinaan Hukum Nasional

\begin{tabular}{ll}
\hline Peraturan LPNK & 4561 \\
\hline Peraturan Lembaga Non Struktural & 404 \\
\hline \multicolumn{1}{c}{ Total } & $\mathbf{3 8 9 9 0}$ \\
\hline Sumber:
\end{tabular}

Sumber: www.jdihn.go.id pertanggal 21 Januari 2020

Tabel 4. Jenis Produk Hukum Tingkat Daerah

\begin{tabular}{ll}
\hline Produk Hukum & Jumlah \\
\hline Peraturan Daerah Provinsi & 4473 \\
\hline Peraturan Daerah Kabupaten & 21197 \\
\hline Peraturan Daerah Kota & 6786 \\
\hline Peraturan DPRD Provinsi & 3 \\
\hline Peraturan DPRD Kabupaten & 5 \\
\hline Peraturan Gubernur & 15579 \\
\hline Peraturan Bupati & 41579 \\
\hline Peraturan Walikota & 15414 \\
\hline Peraturan Desa & 789 \\
\hline Keputusan Gubernur & 17836 \\
\hline Keputusan Bupati & 19280 \\
\hline Keputusan Walikota & 8614 \\
\hline Keputusan DPRD & 140 \\
\hline Instruksi Gubernur & 285 \\
\hline Instruksi Walikota & 7 \\
\hline Surat Edaran & 375 \\
\hline Peraturan Rektor & 9 \\
\hline & $\mathbf{1 5 2 6 1 7}$ \\
\hline Total &
\end{tabular}

Sumber: www.jdihn.go.id pertanggal 21 Januari 2020

Jumlah ini masih sangat mungkin bertambah karena regulasi kita memang selalu bertambah terus setiap waktu. Apabila kita mengakses pangkalan data tersebut pada hari yang lain pasti jumlahnya akan bertambah. Selain itu, belum semua peraturan perundang-undangan, terutama Peraturan Menteri, Peraturan Lembaga Pemerintah Non Kementerian (LPNK) dan Peraturan Daerah dimasukkan dalam pangkalan data (database) baik dalam pangkalan data
Volume 9 Nomor 1, April 2020

(database) peraturan.go.id dari Direktorat Jenderal Peraturan Perundang-undangan maupun pangkalan data (database) jdihn. go.id dari BPHN. Metode yang digunakan oleh kedua pangkalan data tersebut juga tidak sama. Pangkalan data peraturan.go.id hanya memasukkan peraturan perundangundangan saja. Sedangkan pangkalan data jdihn.go.id memasukkan produk hukum baik yang berupa peraturan perundang-undangan juga memasukkan produk hukum yang bukan peraturan perundang-perundangan, misalnya produk hukum yang berupa keputusan, instruksi, maupun surat edaran.

Selain dua pangkalan data (database) di atas, masih ada kementerian atau lembaga yang juga menyediakan pangkalan data (database) peraturan perundang-undangan. Masing-masing pangkalan data (database) dari kementerian atau lembaga kontennya hampir sama. Masalah yang timbul terkait dengan pangkalan data (database) peraturan perundang-undangan adalah jumlah data yang tidak sama antara pengelola pangkalan data (database)yang satu dengan pengelola pangkalan data (database) yang lain. Selain itu, hingga saat ini belum ada lembaga sebagai pengelola tunggal pangkalan data (database) peraturan perundang-undangan yang dapat menyajikan data, terutama jumlah regulasi secara tepat atau pasti. Hingga saat ini masing-masing kementerian atau lembaga membuat pangkalan data (database) dengan caranya sendiri-sendiri dan tidak terintegrasi antara pangkalan data (database) yang satu dengan pangkalan data (data base) yang lainnya. ${ }^{7}$ 
Apabila dilakukan telaah secara mendalam, kondisi regulasi kita baik dari sisi kuantitas maupun kualitas pada saat ini cukup memprihatinkan. Dari sisi kuantitas, keprihatinan ini terkait dengan jumlah regulasi yang terlalu banyak. Terlalu banyaknya regulasi berpotensi berpengaruh terhadap kualitas regulasi yang buruk dan mengarah pada terjadinya ketidakharmonisan, tumpang tindih, konflik antar regulasi. ${ }^{8}$ Regulasi yang buruk juga ikut memberikan kontribusi negatif bagi pelaksanaan kehidupan berbangsa dan bernegara. Sebagai contoh, satu sektor tertentu menjadi bermasalah dalam pelaksanaannya karena ada beberapa regulasi yang mengaturnya atau saling terkait. Karena diatur dalam beberapa regulasi, akibatnya akan terjadi saling konflik antar regulasi. Sebut saja pengaturan dalam bidang berusaha. Kalau seseorang mau berusaha pasti akan berhadapan dengan berbagai regulasi, ditambah lagi instansi yang menanganinya tidak hanya satu, tetapi ada beberapa. Dengan terlalu banyaknya regulasi dalam berusaha dan banyaknya instansi yang menanganinya, akan berdampak pada aktivitas berusaha menjadi tidak mudah. Kondisi semacam ini juga bisa terjadi pada sektor yang lain.

Ada beberapa faktor yang menyebabkan terlalu banyaknya regulasi yang lahir di negara kita. Pertama, banyak orang yang mempunyai pemikiran bahwa semua permasalahan hukum dapat diselesaikan dengan dibuatnya regulasi. Padahal permasalahan hukum yang timbul sebenarnya tidak harus diselesaikan dengan regulasi, tetapi mungkin cukup diselesaikan dengan instrumen lain. Pemikiran semacam ini yang mendorong orang mengarah pada sedikit-sedikit perlu regulasi, sedikit-sedikit perlu regulasi. Kita juga bisa merujuk pada Prolegnas yang target setiap tahunnya minimal 50 RUU dan Prolegnas Jangka Menengah (5 tahunan) di atas 200 RUU. Padahal target tersebut selalu tidak bisa terpenuhi, bahkan separohnya saja tidak sampai. Kedua, setiap pemeriksa (Inspektorat Jenderal, BPK) atau penegak hukum (Kepolisian, Kejaksaan, Hakim) dalam menjalankan tugas dan fungsinya selalu mempersoalkan ada atau tidaknya regulasi yang menjadi payung hukum atau menjadi dasarnya. Apabila tidak ada regulasi sebagai payung hukumnya maka semakin panjang masalahnya. Bisa jadi mengarah pada adanya pelanggaran hukum pidana. Ketiga, dalam penentuan anggaran, Kementerian Keuangan juga sering meloloskan atau tidak meloloskan anggaran kementerian/lembaga berdasarkan ada tidaknya regulasi sebagai payung hukum.

Jumlah regulasi yang terlalu banyak, yang sering juga disebut overregulated, ${ }^{9}$ banjir regulasi, atau obesitas regulasi, dapat mengarah pada regulasi yang berkualitas buruk dan semakin besar potensi untuk terciptanya regulasi yang tidak harmonis (disharmoni). ${ }^{10}$ Regulasi yang buruk akan berakibat pada regulasi yang: 1 . Saling bertentangan antara regulasi yang satu

Vinding: Media Pembinaan Hukum Nasional, (S.I.), v.7, n.3, hlm. 321-334, dec. 2018. ISSN 2580-2364. https:// rechtsvinding.bphn.go.id/ejournal/index.php/jrv/article/view/288/203 (diakses 17 Januari 2020).

8 Ibid.

Ibid.

10 Wicipto Setiadi, Proses Pengharmonisasian Sebagai Upaya Untuk Memperbaiki Kualitas Peraturan Perundangundangan, Jurnal Legislasi Indonesia, Vol. 4 Nomor 2, Juni 2007, Direktorat Jenderal Peraturan Perundangundangan, Departemen Hukum dan HAM RI, hlm. 46. 
dengan regulasi yang lainnya; 2. Tumpang tindih; 3. Multi tafsir; 4. Tidak taat asas; 5. Tidak efektif; 6. Menciptakan beban yang tidak perlu; dan 7. Menciptakan biaya tinggi. ${ }^{11}$

Berdasarkan pada latar belakang yang diuraikan di atas, dapat dikemukakan permasalahan yang sekaligus juga digunakan sebagai pijakan dalam membahas dan mengelaborasi tulisan ini, yaitu: Pertama, Bagaimana cara mengatasi jumlah regulasi yang sudah terlalu banyak dan saling bertentangan, konflik, atau tidak harmonis antara regulasi yang satu dengan regulasi yang lain? Kedua, Pendekatan apa yang diambil dalam rangka mengatasi permasalahan jumlah regulasi yang sudah terlalu banyak dan saling bertentangan, konflik, atau tidak harmonis antara regulasi yang satu dengan regulasi yang lain dan apakah pendekatan tersebut dapat diterapkan di Indonesia?

\section{B. Metode Penelitian}

Pembahasan dalam tulisan ini diarahkan pada penelusuran kepustakaan (library research), pendekatan peraturan perundangundangan (statute approach) dan dokumendokumen lain yang berkaitan dengan pokok bahasan. Dari penelusuran tersebut akan dihasilkan karya tulis yang sistematis dengan menggunakan pendekatan yuridis-analitis dan akan diperoleh hasil yang kualitatif.

Bahan hukum sekunder yang digunakan antara lain buku, karya ilmiah, jurnal, dan hasil penelitian yang berkaitan dengan objek yang dibahas. Pengumpulan data dilengkapi pula dengan artikel hukum dari internet atau pun artikel ilmiah lainnya serta peraturan perundang-undangan yang dapat mendukung kelengkapan data dalam penelitian ini. Data hasil penelitian ini kemudian dianalisis secara mendalam, holistik, dan komprehensif.

\section{Pembahasan}

\section{Simplifikasi atau Penyederhanaan Regulasi}

Berdasarkan pada jumlah regulasi yang sudah terlalu banyak dan mengarah pada regulasi yang buruk tersebut maka cara yang dapat dilakukan adalah apa yang disebut dengan simplifikasi atau penyederhanaan regulasi. Untuk melakukan simplifikasi regulasi, langkah pertama yang dapat dilakukan adalah dengan menginventarisasi regulasi yang bermasalah. Setelah dilakukan inventarisasi maka dilakukanlah evaluasi terhadap efektivitas pelaksaanaan existing regulasi. Opsi terhadap existing regulasi yang bermasalah adalah dilakukan penyederhanaan (simplifikasi), pencabutan dan penggabungan regulasi. Opsi ini harus dilakukan dengan cermat, analisis yang tepat dan dikerjakan oleh tenaga-tenaga profesional yang berintegritas. Dalam rangka meningkatkan kualitas regulasi maka penyederhanaan regulasi menjadi hal yang sangat penting dan mendesak. Namun, harus diakui bahwa penyederhanaan regulasi bukanlah hal yang mudah, karena tidak sekadar menyangkut perubahan rumusan pasal atau ayat semata, akan tetapi memerlukan pendekatan sistemik

11 Workshop "Pemetaan Hasil Identifikasi terhadap Undang-Undang Sektor yang Berpotensi Bermasalah" diselenggarakan oleh Direktorat Analisa Peraturan Perundang-undangan, Badan Perencanaan Pembangunan Nasional (Bappenas), Jakarta, 5 Desember 2012. Lihat juga: Wicipto Setiadi, "Institutional Restructuring to Sustain Regulatory Reform in Indonesia", Hasanuddin Law ReviewVolume 5 Issue 1, April 2019 P-ISSN: 2442 9880, E-ISSN: 2442-9899, hlm. 121-130. 
baik substantif, kelembagaan dan kesadaran hukum. Selain itu, juga harus didukung oleh kemauan politik yang kuat dari para pemimpin negara, terutama Presiden dan harus lebih mengutamakan kepentingan negara daripada kepentingan sektor atau daerah.

Metode simplifikasi dilakukan dengan mengukur relevansi suatu regulasi dengan kriteria yang bersifat mendasar. Kriteria tersebut terkait dengan aspek legalitas, aspek kebutuhan dan aspek kemudahan prosedur (friendly). Aspek legalitas, ditujukan untuk meninjau apakah suatu regulasi dalam pengaturannya tidak ditemui adanya potensi multitafsir dalam perumusan normanya ataupun potensi konflik, duplikasi, inkonsistensi atau bahkan tidak operasional. Aspek kebutuhan, ditujukan untuk meninjau apakah suatu regulasi mempunyai kejelasan tujuan dan didasarkan oleh kebutuhan yang mendasar bagi masyarakat maupun bagi penyelenggara negara. Sedangkan aspek kemudahan prosedur (friendly), ditujukan untuk meninjau apakah sebuah regulasi mudah dipahami dan dipatuhi serta tidak memberikan beban yang berlebihan kepada pihak-pihak yang terkena dampak langsung. Dengan kata lain, tujuan regulasi dapat dicapai tanpa memberikan beban yang tidak perlu bagi kelompok yang terkena dampak pengaturan regulasi tersebut.

\section{Pendekatan Omnibus Law}

Salah satu cara untuk mengatasi banyaknya regulasi yang mengarah pada regulasi yang buruk, maka mulai sekarang kita jangan berpikiran bahwa regulasi merupakan satu- satunya instrument yang dapat mengatasi semua permasalahan hukum. Jangan lagi mempunyai pemikiran, sedikit-sedikit perlu undang-undang atau payung hukum. Sekarang justru harus mempunyai pemikiran sebaliknya, yaitu semakin banyak regulasi akan semakin mengekang kita, semakin mempersulit kita untuk berinovasi dan semakin berpotensi untuk timbul konflik. Semakin sedikit regulasi akan memudahkan kita untuk melakukan inovasi demi kemajuan dan kemakmuran bangsa. Oleh karena itu, untuk mengatasi kondisi semacam ini perlu dilakukan simplifikasi/penyederhanaan regulasi dengan melakukan pemangkasan regulasi. Pemangkasan regulasi dapat dilakukan melalui metode pendekatan Omnibus Law (UU "sapujagat").

Mengapa istilah yang digunakan adalah Omnibus. Pada tahun 1820 di Paris ada "Bus Omni", yaitu kendaraan yang dapat mengangkut banyak orang dengan berbagai jenis barang milik penumpang, pokoknya apa saja bisa masuk. Paris yang pertama menggunakan istilah Omnibus atau bus jenis omni.Baru menjadi istilah generik ketika dipakai di Amerika Latin. Kemudian, Bus Omni menjadi sangat populer, yaitu kendaraan besar sebagai pengangkut berbagai keperluan. Bahkan apa pun yang bisa dipakai ramai-ramai disebut Omnibus. Begitu juga dalam bidang hukum, dikenal "Omnibus Law" yaitu satu UU yang bisa berisi beragam materi. ${ }^{12}$

Dalam referensi ada beberapa pengertian mengenai Omnibus Law. Dari perspektif leksikal, antara lain sebagaimana tercantum dalam Oxford Dictionary of English, kata

12 Dahlan Iskan, Terminal Omni, 14 Desember 2019 artikel yang beredar di media sosial. 
"omnibus" antara lain diartikan sebagai "a volume containing several books previously published separately". Secara harfiah, kata "omnibus" berasal dari Bahasa Latin "omnis" yang bermakna "every" atau "all", atau lebih tepatnya "all, every, the whole, of every kind". Kata "omni" lazimnya dikaitkan dengan sebuah karya sastra yang merupakan hasil penggabungan beragam genre, atau dunia perfilman yang menggambarkan sebuah film yang terbuat dari kumpulan film-film pendek. Dari segi hukum, kata omnibus lazimnya disandingkan dengan kata law atau bill yang berarti suatu peraturan yang dibuat berdasarkan hasil kompilasi beberapa aturan dengan substansi dan tingkatannya berbeda.

Dalam Black'sLaw Dictionary 10th Edition, istilah "omnibus bill" antara lain dimaknai sebagaiberikut: (1) A single bill containing various distinct matters, usually drafted in this way to force the executive either to accept all theunrelated minor provisions or veto the major provision; dan (2) Abill that deals with all proposals relating to a particular subject, such as an "omnibus judgeship bill" covering all proposals for newjudgeships or an "omnibus crime bill" dealing with differentsubject such as new crimes and grants to states for crime control.

Menurut Audrey Obrien, meskipun istilah Omnibus bills sering digunakan, namun tidak ada definisi yang betul-betul tepat. Omnibus bill adalahupaya untuk mengubah, mencabut, atau memberlakukan beberapa undangundang, dan dicirikan oleh fakta bahwa undang-undang tersebut terdiri atas sejumlah inisiatif terkait tetapi terpisah). ${ }^{13}$ Singkatnya, Rancangan Undang-Undang (bill) yang mencakup lebih dari satu aspek yang digabung menjadi satu undang-undang.Sementara Barbara Sinclair menjelaskan omnibus bill merupakan proses pembuatan peraturan yang bersifat kompleks dan penyelesaiannya memakan waktu lama karena mengandung banyak materi meskipun subjek, isu, dan programnya tidak selalu terkait. ${ }^{14}$

Dengan demikian, omnibus law merupakan metode atau konsep pembuatan peraturan yang menggabungkan beberapa aturan yang substansi pengaturannya berbeda, menjadisatu peraturan besar. Ketika peraturan itu diundangkan berkonsekuensi mencabut beberapa aturan yang telah berlaku sebelumnya, baik untuk sebagian maupun secara keseluruhan.Penerapan omnibus law ini lazimnya dikenal di negara yang menganut system common law seperti Amerika Serikat, Filiphina, Australia, dan Inggris serta beberapa negara lain.Dalam konsep omnibus law memungkinkan terbentuknya rancangan undang-undang terpadu (omnibus bill) yang berisi perubahan bahkan penggabungan beberapa undang-undang sekaligus.

Keuntungan menggunakan pendekatan omnibus law dalam pembentukan regulasi, antara lain: 1). Pembahasannya bersifat multisektoral dan menggabungkan banyak undang-undangsehingga waktu pembahasan yang diperlukan lebih cepat dibandingkan dengan mengubahundang-undang tersebut satu persatu; 2). Omnibus law cocok diterapkan di negara yang regulasinya saling tumpang

13 House of Commons Procedure and Practice, Second Edition, 2009, Edited by Audrey O’Brien and Marc Bosc, hlm. 76.

14 Barbara Sinclair, Unorthodox Lawmaking: New Legislative Processes in the U.S. Congress Fourth Edition, 2012. 
tindih, hiper regulasi dan disharmoni; 3). Tujuan penerapan omnibus law adalah untuk menjawab dua hal sekaligus yaitu efisiensi hukum dan harmonisasi hukum; dan 4). Karena menggabungkan banyak regulasi (undang-undang) untuk dibahas dalam satu regulasi (undang-undang), maka efesiensi anggaran negara dalam proses pembentukan regulasi (undang-undang) dapat tercapai.

Sementara itu, sangat mungkin akan ada kekurangannya apabila diterapkan di Indonesia mengingat: Pertama, dikhawatirkan ada ketidaksinkronan dengan sistem hukum Indonesia yang menganut civil law, mengingat konsep omnibus law lebih dikenal penerapannya di negara yang menganut common law. Kedua, karena sifat pembahasannya cepat dan merambah banyak sektor, omnibus law dikhawatirkan akanmengenyampingkan pedoman tata cara pembentukan peraturan perundang-undangan yangdemokratis yaitu memungkinkan mempersempit keterbukaan dan partisipasi publik dalam pembentukan undangundang. Ketiga, waktu pembuatan undangundang yang singkat, rentan mengalami uji materi (judicial review) karenasifatnya yang cenderung tidak memperhatikan prinsip kehati-hatian dan kecermatan dalam proses pembentukannya.

Diskusi yang sering muncul dan menimbulkan pro dan kontra mengenai penerapan pendekatan omnibus law di Indonesia biasanya dikaitkan dengan tradisi sistem Common Law (Anglo Saxon) dihadapkan dengan sistem Civil Law (Eropa Continental). Model pendekatan omnibus law lebih banyak digunakan oleh negara-negara dengan tradisi sistem common law (anglo saxon). Indonesia karena merupakan eks jajahan Belanda maka sistem hukum yang dianut oleh Indonesia sama persis dengan sistem hukum Belanda, yaitu tradisi Civil Law (Eropa Continental) yang lebih mengutamakan pada sendi peraturan perundang-undangan (regulasi). Bahkan dikenal juga apa yang disebut dengan asas konkordansi (concordantie), yaitu apa yang berlaku di Belanda berlaku juga di Indonesia. Contoh di Belanda berlaku Wetbook van Strafrecht (WvS) - Kitab Undang-Undang Hukum Pidana (KUHP), di Indonesia juga berlaku KUHP (terjemahan WvS), di Belanda berlaku Burgerlijk Wetboek $(B W)$ - Kitab Undang-Undang Hukum Perdata (KUHPerdata), di Indonesia juga berlaku KUHPerdata (terjemahan BW). KUHP dan KUHPerdata kita merupakan terjemahan dari bahasa Belanda ke bahasa Indonesia. Terjemahan yang kita gunakan pun bukan terjemahan resmi yang dikeluarkan oleh pemerintah. Oleh karena itu, hingga saat ini kita belum mempunyai KUHP dan KUHPerdata yang bersifat nasional.

Sedangkan negara-negara dengan tradisi sistem common law (anglo saxon) lebih mengutamakan pada kasus/putusan pengadilan. Putusan pengadilan atau yurisprudensilah yang menjadi sumber hukum utama. Dalam sistem common law (anglo saxon) dianut doktrin stare decicis atau sistem preseden. ${ }^{15}$ Pada sistem ini hakim terikat untuk mengikuti putusan pengadilan terdahulu untuk kasus yang serupa. Meskipun demikian, tetap saja ada kemungkinan

15 Nurul Qomar, Perbandingan Sistem Hukum dan PeradilanCivil Law System dan Common Law System, (Makasar: Pustaka Refleksi, 2010), hlm 47. 
adanya penyimpangan oleh hakim asal dapat dibuktikan fakta yang dihadapi berbeda dengan fakta yang telah diputus oleh pengadilan terdahulu.

Namun, seiring perkembangan dunia saat ini yang semakin mendekati tanpa batas (borderless), perbedaan pengutamaan sendi di atas sebetulnya sudah tidak bisa lagi ditarik garis yang ketat, tidak perlu dipermasalahkan lagi, dan sudah tidak terlalu relevan lagi karena kedua sistem tersebut justru saling mengisi dan saling melengkapi. Selain itu, dalam praktik Indonesia sebetulnya juga sudah menerapkan penyusunan regulasi melalui pendekatan omnibus law, meskipun pada saat pembentukannya tidak disebut dengan tegas pendekatannya melalui omnibus law. Karena tidak disebutkan dengan tegas pendekatan pembentukannya menerapkan pendekatan omnibus law, maka tidak menimbulkan perdebatan panjang yang mengarah pada pro dan kontra seperti saat ini.

Ada beberapa contoh cukup menarik yang bisa diambil dalam rangka penyusunan regulasi dengan menggunakan pendekatan omnibus law. Pada pemerintahan Presiden Jokowi Jilid 1 pernah dikeluarkan Paket Kebijakan Ekonomi (PKE), meskipun terbatas pada Peraturan Pemerintah (PP) ke bawah, yaitu Peraturan Presiden (Perpres) dan Peraturan Menteri (Permen). PKE ini dilakukan melalui deregulasi terhadap kurang lebih 222 regulasi. PKE ini tidak terlalu sulit karena PP, Perpres dan Permen dibuat oleh kekuasaan eksekutif (di bawah kekuasaan Presiden). Berbeda halnya dengan UU yang dibuat bersama antara DPR dan Presiden, yang biasanya diperlukan koordinasi yang lebih panjang serta tarik ulur kepentingan politik.
Cara lain yang dilakukan dalam rangka menyusun regulasi dengan pendekatan omnibus lawadalah melaluipola pembentukan undang-undang dengan menggabungkan 2 atau lebih materi muatan yang diatur dalam UUD NRI Tahun 1945. Misalnya UndangUndang Nomor 17 Tahun 2014 tentang MPR, DPR, DPD dan DPRD (MD 3) yang merupakan gabungan pengaturan dari Pasal 2, Pasal 18, Pasal 19, Pasal 20A, Pasal 22B, Pasal 22C, dan Pasal 22D UUD NRI Tahun 1945. Dengan demikian, pola ini merupakan delegasian beberapa pasal dalam UUD NRI Tahun 1945 tapi diatur dalam 1 (satu) undang-undang saja, bukan pendelegasian pasal per pasal yang akan menghasilkan 1 (satu) undang-undang setiap pasal. Cara seperti ini juga sudah lazim dilakukan terhadap delegasian dari undangundang ke peraturan pelaksanaannya, baik PP maupun Perpres. Peraturan pelaksanaan dari undang-undang tersebut biasanya dijadikan satu, misal Peraturan Presiden No. 87 Tahun 2014 tentang Peraturan Pelaksanaan Undang-Undang No. 12 Tahun 2011 tentang Pembentukan Peraturan PerundangUndangan. Model semacam ini sudah banyak dilakukan pada saat membentuk peraturan pelaksanaan delegasian dari berbagai undang-undang.

Pola lain adalah pola yang digunakan dalam pembentukan Undang-Undang No. 23 Tahun 2014 tentang Pemerintahan Daerah (UU Pemda), Undang-Undang No. 17 Tahun 2014 tentang MPR, DPR, DPD, DPRD (UU MD3). Undang-Undang Pemerintahan Daerah berdampak pada 4 undang-undang yang sudah ada sebelumnya, yaitu mencabut dua undang-undang, yakni Undang-Undang No. 5 Tahun 1962 tentang Perusahaan Daerah 
dan Undang-Undang No. 32 Tahun2004 tentang Pemerintahan Daerah dan beberapa ketentuan dalam Undang-Undang MD3 serta Undang-Undang No. 28 Tahun2009 tentang Pajak Daerah dan Retribusi Daerah.

Model lain penggunaan pendekatan omnibus law juga dilakukan dalam rangka penyusunan Undang-Undang No. 13 Tahun2003 tentang Ketenagakerjaan. Pendekatan yang digunakan dalam menyusun UU Ketenagakerjaanadalah menyusun ketentuan-ketentuan baru yang disesuaikan dengan kebutuhan pada saat itu dan ketentuan lama yang diatur dalam peraturan perundangundangan lama dicabut. Untuk menampung rumusan ketentuan baru tersebut, UndangUndang No. 13 Tahun 2003 mencabut dan menyatakan tidak berlaku 6 ordonansi dan 9 undang-undang sekaligus

Ordonansi yang dicabut oleh UndangUndang No. 13 Tahun 2003 tentang Ketenagakerjaan adalah: 1 . Ordonansi tentang Pengerahan Orang Indonesia Untuk Melakukan Pekerjaan di Luar Indonesia (Staatsblad Tahun 1887 Nomor 8); 2. Ordonansi tentang Pembatasan Kerja Anak dan Kerja Malam Bagi Wanita (Staatsblad Tahun 1925 Nomor 647); 3. Ordonansi tentang Kerja Anak-anak dan Orang Muda di Atas Kapal (Staatsblad Tahun 1926 Nomor 87); 4. Ordonansi tentang Pengaturan Kegiatan-kegiatan Mencari Calon Pekerja (Staatsblad Tahun 1936 Nomor 208); 5. Ordonansi tentang Pemulangan Buruh yang Diterima atau Dikerahkan dari Luar Indonesia (Staatsblad Tahun 1939 Nomor 545); dan 6. Ordonansi tentang Pembatasan Kerja Anakanak (Staatsblad Tahun 1949 Nomor 8).

Sedangkan undang-undang yang dicabut oleh Undang-Undang No. 13 Tahun 2003 tentang Ketenagakerjaan adalah: 1). Undang-
Undang No. 1 Tahun 1951 tentang Pernyataan Berlakunya Undang-Undang Kerja Tahun 1948 Nomor 12 dari Republik Indonesia Untuk Seluruh Indonesia; 2). Undang-Undang No. 21 Tahun 1954 tentang Perjanjian Perburuhan Antara Serikat Buruh dan Majikan; 3). Undang-Undang No. 3 Tahun 1958 tentang Penempatan Tenaga Asing; 4). UndangUndang No. 8 Tahun 1961 tentang Wajib Kerja Sarjana; 5). Undang-Undang No. 7 Pnps Tahun 1963 tentang Pencegahan Pemogokan dan/ atau Penutupan (Lock Out) Di Perusahaan, Jawatan, dan Badan Yang Vital; 6). UndangUndang No. 14 Tahun 1969 tentang Ketentuanketentuan Pokok Mengenai Tenaga Kerja; 7). Undang-Undang No. 25 Tahun 1997 tentang Ketenagakerjaan; 8). Undang-Undang No. 11 Tahun 1998 tentang Perubahan Berlakunya Undang-Undang No. 25 Tahun 1997 tentang Ketenagakerjaan; 9). Undang-Undang No. 28 Tahun 2000 tentang Penetapan Peraturan Pemerintah Pengganti Undang-Undang No. 3 Tahun 2000 tentang Perubahan Atas Undang-Undang No. 11 Tahun 1998 tentang Perubahan Berlakunya Undang-Undang No. 25 Tahun 1997 tentang Ketenagakerjaan Menjadi Undang-Undang.

Pencabutan dan pernyataan tidak berlaku terhadap banyak regulasi yang berdampak merugikan pada pihak-pihak terkait biasanya akan mendapatkan penolakan atau resistensi. Sebagai contoh adalah adanya pro dan kontra terhadap RUU tentang Cipta Kerja inisiatif Pemerintah yang sudah disampaikan kepada DPR. RUU tentang Cipta Kerja dalam pembentukannya menerapkan pendekatan omnibus law dengan menyusun norma baru dan mencabut dan menyatakan tidak berlaku serta merevisi norma-norma yang diatur dalam 80 -an undang-undang. Apabila pencabutan 
dan pernyataan tidak berlaku serta revisi dari regulasi tersebut dianggap merugikan, maka akan menimbulkan penolakan atau resistensi dari kalangan yang kepentingannya dirugikan. Sampai saat ini RUU tentang Cipta Kerja belum jelas nasibnya, ada yang berpendapat sebaiknya Pemerintah menarik kembali RUU tersebut. Sementara Pemerintah berpendapat bahwa apa yang disampaikan kepada DPR kan masih rancangan sifatnya, jadi masih dapat dilakukan perbaikan atau penyempurnaan pada waktu RUU tersebut dibahas bersama antara DPR dan Pemerintah.

Berdasarkan pada timbulnya pro dan kontra terhadap RUU tentang Cipta Kerja, maka langkah-langkah yang perlu dilakukan dalam penyusunan regulasi melalui pendekatan omnibus law adalah melakukan kajian yang betul-betul medalam dan secara komprehensif. Kajian ini dilakukan dalam bentuk Naskah Akademik, termasuk mengenai analisis biaya dan menfaatnya (cost and benefit analysis). Selanjutnya, dilakukan inventarisasi berapa banyak regulasi yang ada dan regulasi apa saja yang terdampak dan tindakan hukum apa yang perlu dilakukan terhadap regulasi terdampak, apakah dicabut, diganti, direvisi, atau tindakan hukum lainnya.

Prinsip yang harus diperhatikan dalam melakukan simplifikasi regulasi melalui pendekatan omnibus law adalah lebih mengedepankan asas lex posterior derogate legi priori (aturan yang baru mengenyampingkan aturan sebelumnya) dengan diikuti pengaturan dalam "ketentuan penutup" untuk membatalkan regulasi yang hendak dibatalkan. Omnibus law akan mengenyampingkan asas lex spesialis derogate legi generalis (aturan yang khusus mengenyampingkan aturan yang umum), karena omnibus law ini dapat dikatakan mengatur lebih umum. Meskipun demikian, asas ini tetap menjadi pertimbangan bagi para pembentuk/perancang peraturan perundangundangan untuk tetap menaatinya pada waktu menyusun peraturan perundang-undangan tersebut.

Berikut ini beberapa hal yang dapat dijadikan pertimbangan dalam menerapkan pendekatan omnibus law. Pertama, dalam membentuk regulasi dengan menerapkan pendekatan omnibus law jangan sampai regulasi baru dibuat hanya semata-mata mempertimbangkan pada satu sudut pandang saja, misalnya hanya untuk kepentingan peningkatan investasi saja tanpa mempertimbangkan kepentingan lain, seperti perlindungan lingkungan, hak-hak tenaga kerja, kondisi daerah, dan aspek-aspek lainnya sebagai pertimbangan filosofi dari regulasi yang akan terkena dampak pencabutannya. Pendekatan yang dilakukan harus secara komprehensif, multidisiplin, multisektor. Kedua, mengingat kedahsyatannya sebaiknya pendekatan omnibus law jangan sampai disusupi banyak kepentingan, terutama kepentingan politik, sehingga rawan disalahgunakan. Ketiga, sebaiknya dipilih pola pendekatan omnibus law terbatas (per sektor), karena mekanismenya jauh lebih aman dan sangat dimungkinkan secara praktik, mengingat dalam kelembagaan eksekutif sudah terbagi menjadi kementerian/lembaga yang masingmasing memiliki tugas dan fungsinya dan di DPR jugatelah terbagi menjadi komisi-komisi. Dengan pendekatan omnibus law terbatas maka memudahkan penentuan kementerian 
yang menjadi leader dalam pembentukan regulasi, begitu pula penentuan komisi di DPR yang menangani.

Keempat, perlu menyusun Prolegnas berdasarkan tema-tema, tidak sekadar kuantitas sembari merevisi UU yang sudah lama, guna menyesuaikan dengan perkembangan keadaan saat ini dengan tetap mempertimbangkan nilai-nilai keadilan pada saat UU itu dibuat. Jangan terlalu banyak mengusulkan RUU baru, kalau perlu dilakukan moratorium usulan RUU baru agar pendekatan omibus law bisa berhasil. Kelima, idealnya selama dilakukan simplifikasi/penyederhanaan regulasi, semestinya dibarengi dengan moratorium usulan pembentukan regulasi baru karena kalau masih dilakukan pembentukan regulasi baru tanpa melakukan simplifikasi/ penyederhanaan regulasi dikhawatirkan tetap akan terjadi tumpang tindih, ego sektoral dan sebagainya. Moratorium regulasi pastibanyak yang tidak sepakat karena masih banyak lembaga, termasuk DPR yang mempunyai "keinginan" dibentuknya regulasi sebagai payung hukum. Bahkan ada pejabat yang ingin meninggalkan "warisan" regulasi pada masa memimpin lembaga tersebut.

Keenam, kalau pun akan diusulkan regulasi baru maka perlu dilakukan pendekatan baru yang berbeda dengan pendekatan sebelumnya. Tidak hanya sekadar kuantitas (banyaknya) regulasi tetapi lebih diarahkan pada kualitas regulasi demi terwujudnya kesejahteraan dan kemakmuran rakyat. Penyusunan regulasi baru sebaiknya dilakukan dengan pendekatan: a. Mengurangi tumpang tindih regulasi; b. Berorientasi pada tujuan; c. Kemudahan prosedur; d. Memangkas regulasi yang bermasalah; dan e. Paradigma "semua boleh kecuali yang dilarang".

Dengan demikian, pembentukan regulasi baru dimungkinkan setelah melalui kajian atau analisis yang mendalam baik dari segi kemanfaatan maupun biayanya.

\section{Penutup}

Sebagai bagian akhir dari tulisan ini, disampaikan penutup yang terdiri atas kesimpulan dan saran sebagai berikut. Dengan adanya hyper regulasi yang mengakibatkan terjadinya tumpang tindih, konflik dan disharmonisasi regulasi selama ini, maka Indonesiamemang perlu melakukan terobosan baru dalam rangka penyederhanaan/ simplifikasi regulasi.Penyederhanaan/ simplifikasi regulasi dilakukan dengan menerapkan pendekatan omnibus law. Pembentukan atau penyusunan regulasi dengan menggunakan pendekatan omnibus law di Indonesia bukanlah hal yang baru dan dapat diterapkan di Indonesia meskipun Indonesia lebih mengutamakan sendi hokum civil law. Penerapan konsep omnibus law dalam pembentukan peraturan perundangundangan di Indonesia harus dilakukan secara cermat dan hati-hati dengan memperhatikan prinsip-prinsip sebagai berikut: 1). Sejalan dengan nilai-nilai yang terkandung dalam Pacasila dan konstitusi; 2). Sesuai dengan peraturan perundang-perundangan yang mengatur tentang pembentukan peraturan perundang-undangan; 3). Tetap menjaga keharmonisan antara regulasi yang satu dengan regulasi yang lain.

Pembentukan regulasi dengan menggunakan pendekatan omnibuslaw harus senantiasa memperhatikan beberapa 
hal,antara lain: 1). Berpedoman pada Pancasila sebagai landasan filosofis (staatsfundamentalnorm) dan Konstitusi Negara yaitu Undang-Undang Dasar Negara Republik Indonesia Tahun 1945 sebagai landasan konstitusional; 2). Berpedoman pada peraturan perundang-undangan yang terkait dengan kaidah serta norma pembentukan peraturan perundangundangan; 3). Karena banyak undang-undang yang terdampak, diharapkan baik pemerintah maupun DPR memberikan jangka waktu pembahasan yang rasional agar semua pihak dapat turut serta menelaah, mengkaji, dan berkontribusi dalam pembentukan undangundang yang bersangkutan, sehingga meminimalkan atau bahkan menghilangkan pendapat yang menentangataukontra; 4). Seyogianya sebanyak mungkin melibatkan unsur masyarakat dan seluruh pemangku kepentingan (stakeholders) sebagai bentuk pemenuhan hak masyarakat dalam menyusun kebijakan publik.

\section{Daftar Pustaka}

\section{Buku}

Asshiddiqie, Jimly, Konstitusi Keadilan Sosial, Serial Gagasan Konstitusi Sosial Negara Kesejahteraan Sosial Indonesia, (Jakarta: Penerbit Buku Kompas, 2018).

Asshiddiqie, Jimly, Konstitusi Kebudayaan dan Kebudayaan Konstitusi,(Malang: Intrans Publishing, 2017).

Bappenas,Strategi Nasional Reformasi Regulasi: Mewujudkan Regulasi yang Sederhana dan Tertib, (Jakarta: Bappenas, 2015).

Black Law Dictionary, 10th Edition, Thomson West.

Junaidi, Muhammad, Hukum Kosntitusi Pandangan dan Gagasan Modernisasi Negara Hukum. (Jakarta: Rajawali Pers, 2018).

Mahfud, Moh.,Politik Hukum di Indonesia. (Jakarta: Rajawali Pers, 2017).
Mas, Marwan, Hukum Konstitusi dan Kelembagaan Negara, (Jakarta: Rajawali Pers, 2018).

O'Brien, Audrey and Marc Bosc, House of Commons Procedure and Practice Second Edition, (2009).

Oxford Dictionary of English

Qomar,Nurul,Perbandingan Sistem Hukum dan PeradilanCivil Law System dan Common Law System, (Makasar: Pustaka Refleksi, 2010).

Soeprapto, Maria Farida Indrati,IImu Perundangundangan, (Jakarta: Kanisius, 1998).

\section{Makalah/Artikel/Prosiding/Hasil Penelitian}

Badan Perencanaan Pembangunan Nasional (Bappenas), Pemetaan Hasil Identifikasi terhadap Undang-Undang Sektor yang Berpotensi Bermasalah, (Workshop diselenggarakan oleh Direktorat Analisa Peraturan Perundang-undangan, Badan Perencanaan Pembangunan Nasional, (Jakarta, 5 Desember 2012).

Badan Perencanaan Pembangunan Nasional (Bappenas), Regulatory Reform in Indonesia, (Workshop diselenggaraakan oleh Bappenas \& OECD, Jakarta, 25 Maret 2015).

Sadiawati, Diani, Sinergitas Kebijakan dan Regulasi Dalam Menghadapi Tantangan Global, (Seminar NasionalReformasi Hukum, Sekretariat Kabinet RI, Jakarta, 28 November 2018).

Sekretariat Kabinet RI, Seminar Nasional Reformasi Hukum: Menuju Peraturan Perundangundangan yang Efektif dan Efisien,(Jakarta, 28 November 2018).

Setiadi, Wicipto, "Proses Pengharmonisasian Sebagai Upaya Untuk Memperbaiki Kualitas Peraturan Perundang-undangan",Jurnal Legislasi Indonesia, Vol. 4 Nomor 2, (Juni 2007).

Setiadi, Wicipto, "Pembangunan Hukum Dalam Rangka Peningkatan Supremasi Hukum (Development of Law in Order to Enhancement Supremacy of Law)",Jurnal Rechtsvinding: Media Pembinaan Hukum Nasional, Vol. 1 Nomor 1, (April 2012).

Setiadi, Wicipto, "Urgensi Reformasi Regulasi Dalam Rangka Mendukung Pembangunan Nasional", Majalah Hukum Nasional, (2014).

Setiadi, Wicipto, "Simplifikasi Peraturan Perundang-undangan Dalam Rangka Mendukung Kemudahan Berusaha 
(Simplification of Regulations in Order to Support Ease of Doing Business)",Jurnal Rechtsvinding: Media Pembinaan Hukum Nasional, https://rechtsvinding.bphn.go.id/ ejournal/index.php/jrv/article/view/288/203. (diakses pada 24 Desember 2018).

Setiadi, Wicipto, "Institutional Restructuring to Sustain Regulatory Reform in Indonesia", Hasanuddin Law Review, Volume 5 Issue 1, (April 2019).

Setiadi, Wicipto, Indonesia Negara Peraturan?, Koran Sindo, Kamis, 21 November 2019.

Yusuf, Asep Warlan, Bimtek Penyusunan Naskah Akademik, Badan Pembinaan Hukum Nasional, (Jakarta, 16 - 18 Juli 2012).

\section{Peraturan}

Undang-Undang Dasar Negara Republik Indonesia Tahun 1945.

Undang-Undang Nomor 17 Tahun 2014 tentang MPR, DPR, DPD, dan DPRD.

Undang-Undang No. 23 Tahun 2014 tentang Pemerintahan Daerah

Undang-Undang No. 12 Tahun 2011 tentang Pembentukan Peraturan Perundangundangan.

Undang-Undang No. 13 Tahun 2003 tentang Ketenagakerjaan.

\section{Internet}

Dahlan Iskan. Terminal Omni, 14 Desember 2019 artikel yang beredar di media sosial.

http://www. peraturan.go.id/

http://www.jdihn.go.id/ 